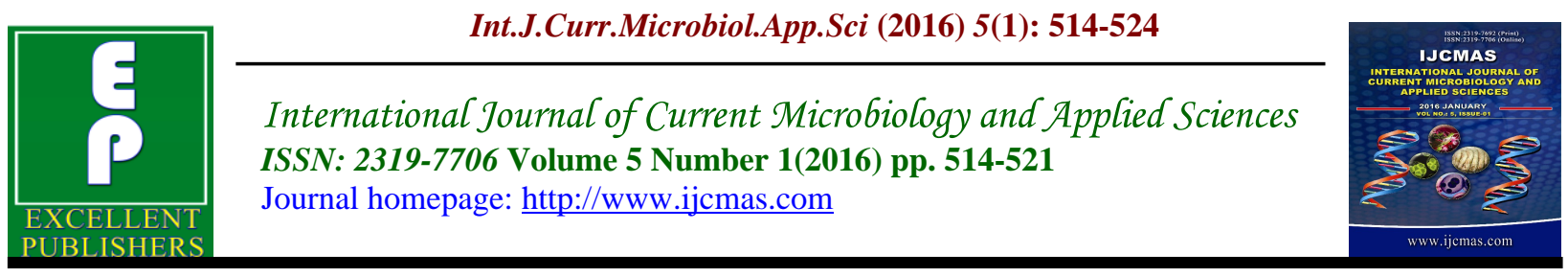

Original Research Article

hittp://dx.doi.org/10.20546/ijcmas.2016.501.05i

\title{
Isolation and Identification of Pectinolytic Bacteria from Soil Samples of Akola Region, India
}

\author{
G.A. Aaisha and D.L. Barate* \\ Department of Microbiology, Shri Shivaji College Arts, Science and Commerce, \\ Akola, M.S, India \\ *Corresponding author
}

\begin{abstract}
A B S T R A C T
Keywords

Pectinase,

Pectinolytic

activity,

Vincent's agar

medium,

Galacturonic

Article Info

Accepted:

22 December 2015

Available Online:

10 January 2016

Pectin is a major component of primary cell wall of all plants and encompasses a range of galacturonic rich polysaccharides. Pectinase hydrolyses pectic substance, they have a share of $25 \%$ in the global sales of food enzymes. The present work has been undertaken for the screening and isolation of pectinase producing bacteria from soil samples collected from farms of various regions of Akola. Total 70 bacterial strains were isolated from 12 soil samples. Preliminary screening of pectinase producing bacterial strains was done by spot inoculation on Vincent's agar medium containing pectin. Out of 70 isolates, 36 were found to be positive for pectinolytic activity giving clear zones ranging from 7-35 $\mathrm{mm}$. The pectinase producing isolates were subjected for further identification by Standard Conventional methods. The isolates were found to be Bacillus spp, Pseudomonas spp and Staphylococcus aureus. In further study, 4 most prominent pectinase producing isolates were identified as Bacillus firmus (P1), Bacillus coagulans (P13), Bacillus endophyticus (P57) and Bacillus vietnamensis (P58) In the present study, an attempt was made to isolate efficient pectinase producing bacteria from the diverse region of Akola.
\end{abstract}

\section{Introduction}

Enzymes are delicate protein molecules necessary for life. Pectin is a polymeric material having carbohydrate group esterifies with methanol. It is an important component of plant cell wall. It is present in highest concentration in the middle lamella, where it acts as a cementing substance between adjacent cells. Plant pathogens attack target cells by producing number of cell degrading enzyme which facilitate the entry and expansion of pathogen in the host tissue. Pectinases are a group of enzymes that breakdown pectins. The history of pectinases began with an understanding the structure of pectine substances and the mechanism by which pectolytic enzymes degrade pectic substances. Later the microbial production of pectinase became prominent for many decades. Many microorganisms viz. Bacteria, Yeast, Fungi 
could produce pectinases. Many plant pathogenic bacteria and fungi are known to produce pectinolytic enzymes useful for invading host tissues. Moreover, these enzymes are essential in the decay of dead plant material by pathogenic microorganisms and thus assist in recycling carbon compounds in the biosphere (Marcia et al., 1999).

Among the various pectinase, bacterial extracellular pectinase are the most significant, compared with animals, plants, viruses and fungal extracellular pectinase. Extracellular pectinase produced by Bacillus and Cocci species are of main interest from a biotechnology perspective, and are not only in scientific fields of protein chemistry and proteins engineering but also in applied fields such as foods, pharmaceutical and paper industries. These pectinases account for $10 \%$ of the total worldwide production of enzyme. The genus Bacillus and Cocci contains a number of industrially important species and approximately half of the present commercial production of bulk enzymes derives from the single class of enzymes which play an important part in the metabolism of almost all organisms. In the present study, an attempt was made to isolate efficient pectinase producing bacteria from the diverse region of Akola.

\section{Materials and Methods}

Soil samples were collected from 12 different regions of Akola district. Pectinolytic bacteria were isolated from collected soil samples by serial dilution method and spread on Vincent's agar plates. Serial dilution was done by taking one gram of soil in $100 \mathrm{ml}$ distilled water in a flask. 1 $\mathrm{ml}$ suspension from flask was taken into test tube containing $9 \mathrm{ml}$ of sterile distilled water and $1 \mathrm{ml}$ from one to another, dilutions were made upto $10^{-5}, 0.1 \mathrm{ml}$ of sample spread on petri plates from last two dilutions and these plates were incubated at $37^{\circ} \mathrm{C}$ for 24 hours. After incubation mixed cultures were obtained which were purified by streaking on agar plates.

\section{Primary Screening}

Screening was done by the spot inoculation method. Isolated cultures were inoculated on the Vincent's agar plate for the screening of pectinase producing bacteria by spots inoculation method and plates were kept for incubation at $37^{\circ} \mathrm{C}$ for 24 hours, to screen the pectinase activity of the obtained cultures. After incubation period plates were observed for the formation of clear zone around the colonies by flooding Iodine solution on the plates. (Venkata et al., 2013)

\section{Secondary Screening}

The secondary screening for pectinase producing bacteria was done by the Well diffusion method (Lalitha et al., 2013). Nutrient broth was prepared and inoculated with each isolate in separate tubes. $1 \mathrm{ml}$ of cell free supernatant was poured on the Vincent's agar well of diameter $5 \mathrm{~mm}$ prepared in plates by sterile cork borer. After pouring the broth cultures, plates were incubated at $37^{\circ} \mathrm{C}$ for 24 hours. After incubation plates were flooded with the Iodine solution, and the zone of clearance was observed. The cultures which showed highest zones were selected for further study.

\section{Study of Growth Parameters of Isolates Showing Maximum Pectinase Production}

Bacterial isolates were subjected to different culture conditions to derive some of the optimum growth conditions for pectinase production. Growth parameters such as growth curve, effect of Temperature and 
effect of $\mathrm{pH}$ were studied in order to detect the optimum parameters.

\section{Growth Curve}

In order to detect the growth curve, $100 \mathrm{ml}$ nutrient broth was prepared and autoclaved. Loopful of culture was inoculated in it and incubated in shaker for 24 hours. After incubation optical density was taken at 600 $\mathrm{nm}$ everyday till the decline phase did not reach and checked the optimum growth.

\section{Effect of Temperature}

Temperature plays an important role for the pectinase production. The effect of temperature on pectinase production was studied by inoculating culture in $100 \mathrm{ml}$ nutrient broth and incubated at various temperatures, 10, 20, 30, 37, 40, 50, 60, 70 and $80^{\circ} \mathrm{C}$. After incubation optical density was taken at $600 \mathrm{~nm}$ to check optimum growth.

\section{Effect of pH}

The effect of $\mathrm{pH}$ for pectinase production was determined by inoculating and incubating the bacterial culture in the nutrient broth with different $\mathrm{pH}$. The experiment was carried out individually at various $\mathrm{pH} 5,6,7,8,9$ and 10 . The optical density was checked after 24 hours at 600 nm.

\section{Results and Discussion}

Total 70 isolates were obtained from soil samples by serial dilution method and the isolates were screened for the pectinolytic activity. In primary screening, 36 bacterial colonies showed zone of clearance which further were selected for secondary screening. These isolates were classified as good, fair and excellent producers, selected on the basis of zone diameter for their pectinase activity. In secondary screening 4 isolates were found to be excellent producers which were probably identified as, Bacillus firmus (P1), Bacillus coagulans (P13), Bacillus endophyticus (P57) and Bacillus vietnamensis (P58). Different growth parameters were carried out in which the maximum growth was observed at 72 hours, the optimum temperature for pectinase production was found at $37^{\circ} \mathrm{C}$, where by the maximum pectinase production was observed at $\mathrm{pH} 8$.

In the present study, isolation and screening of pectinase producing bacteria was carried out from the agricultural soil. For this soil samples were collected from different places of Akola region. The isolation was carried out first by serial dilution of soil samples on Vincent's agar medium as performed by Kumari et al., The serially diluted soil samples were screened for pectinase producing bacteria on Vincent's agar plate. Out of 70 bacteria, 36 bacteria showed zone of clearance after pouring iodine solution in primary screening. In secondary screening 4 isolates showed high zones of clearance out of 36 isolates.

All 36 bacterial isolates were characterised based on Gram staining and several biochemical reactions. The probable isolates were found to be as, Bacillus licheniformis (7), Bacillus badius (4), Bacillus asahin (2), Bacillus psychrosaccharolyticus (4), Pseudomonas aeruginosa (7), Pseudomonas fluroscens (4), Staphylococcus sureus (3), Bacillus firmus (1), Bacillus coagulans (1), Bacillus endophyticus (1), Bacillus vietnamensis (1) (Table 1 \& 2). This is in agreement with other studies who also reported isolates from these genus are good sources for production of pectinase. (Venkata et al., 2013; Torimiro et al., 2013; Anam et al., 2012; Kashyap et al., 2000; Kumar et al.,2012; Sunil et al., 2013; Divakar et al., 2013). 
Table.1 Cultural and Morphological Characteristics of Isolates

\begin{tabular}{|c|c|c|c|c|}
\hline \multirow{2}{*}{ Characteristics } & \multicolumn{4}{|c|}{ Isolates } \\
\hline & P1 & P13 & P57 & P58 \\
\hline \multicolumn{5}{|c|}{ Morphological, Cultural Characteristics of isolates } \\
\hline Size & $1-12 \mathrm{~mm}$ & $1-3 \mathrm{~mm}$ & $1-3 \mathrm{~mm}$ & $2-3 \mathrm{~mm}$ \\
\hline Shape & Oval & Circular & Circular & Circular \\
\hline Margin & Entire & Entire & Entire & Entire \\
\hline Elevation & Raised & Raised & Raised & Flat \\
\hline Colour & Cream & White & White & White \\
\hline Surface & Rough & Smooth & Rough & Smooth \\
\hline Opacity & Opaque & Convex & Opaque & Opaque \\
\hline Motility & Motile & Motile & Non-motile & Motile \\
\hline Endospore formation & Spore forming & Spore forming & Spore forming & Spore forming \\
\hline Gram character & $\begin{array}{c}\text { Gram +ve Long } \\
\text { rods }\end{array}$ & $\begin{array}{l}\text { Gram +ve } \\
\text { Long rods }\end{array}$ & $\begin{array}{l}\text { Gram +ve } \\
\text { Long rods }\end{array}$ & $\begin{array}{l}\text { Gram +ve } \\
\text { Short rods }\end{array}$ \\
\hline \multicolumn{5}{|c|}{ Biochemical Characteristics of Isolates } \\
\hline \multicolumn{5}{|l|}{$\begin{array}{l}\text { Carbohydrate } \\
\text { Fermentation Test }\end{array}$} \\
\hline Glu A/G & $+/+$ & $+/-$ & $+/-$ & $-/-$ \\
\hline Suc A/G & $+/-$ & $-/-$ & $+/-$ & $-1-$ \\
\hline $\operatorname{Man} A / G$ & $+/-$ & $-/-$ & $+/-$ & $-/-$ \\
\hline Mal A/G & $+/-$ & $+/-$ & $+/-$ & $-1-$ \\
\hline Lac A/G & $-/-$ & $-/-$ & $-/-$ & $-/-$ \\
\hline \multicolumn{5}{|l|}{ Enzymes Test } \\
\hline Amylase & + & + & - & + \\
\hline Urease & - & - & + & + \\
\hline Gelatinase & + & - & + & + \\
\hline Catalase & + & + & + & + \\
\hline Oxidase & + & - & + & + \\
\hline \multicolumn{5}{|l|}{ IMViC Test } \\
\hline Indol & - & - & - & - \\
\hline MR & + & + & - & - \\
\hline VP & - & - & - & - \\
\hline Citrate & - & - & + & + \\
\hline
\end{tabular}

\begin{tabular}{|c|c|c|c|c|}
\hline $\begin{array}{l}\text { Probable } \\
\text { isolates }\end{array}$ & Bacillus firmus & $\begin{array}{l}\text { Bacillus } \\
\text { coagulans }\end{array}$ & $\begin{array}{l}\text { Bacillus } \\
\text { endophyticus }\end{array}$ & $\begin{array}{l}\text { Bacillus } \\
\text { vietnamensis }\end{array}$ \\
\hline
\end{tabular}


Fig.1: Primary screening of pectinase producing isolates

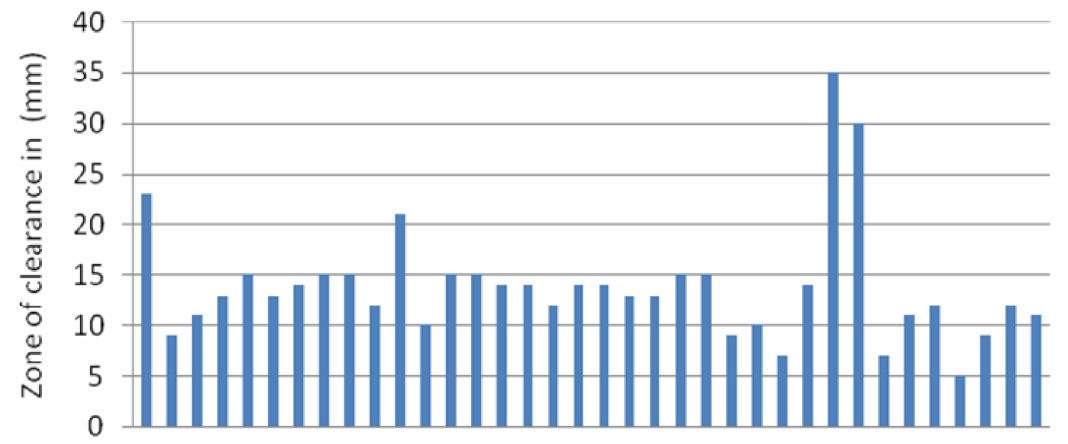

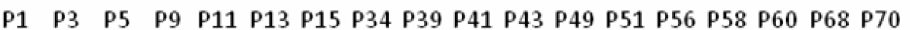
Isolates

Fig.2: Distribution of Pectinolytic bacteria from total

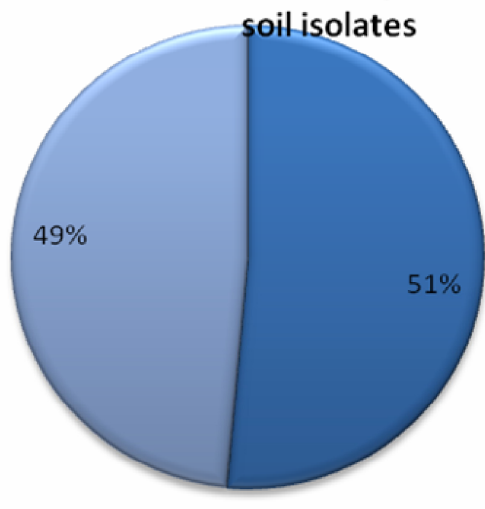

- Pectinase Producers

Fig. 3 : Most Prominent Pectinase producers from secondary screening

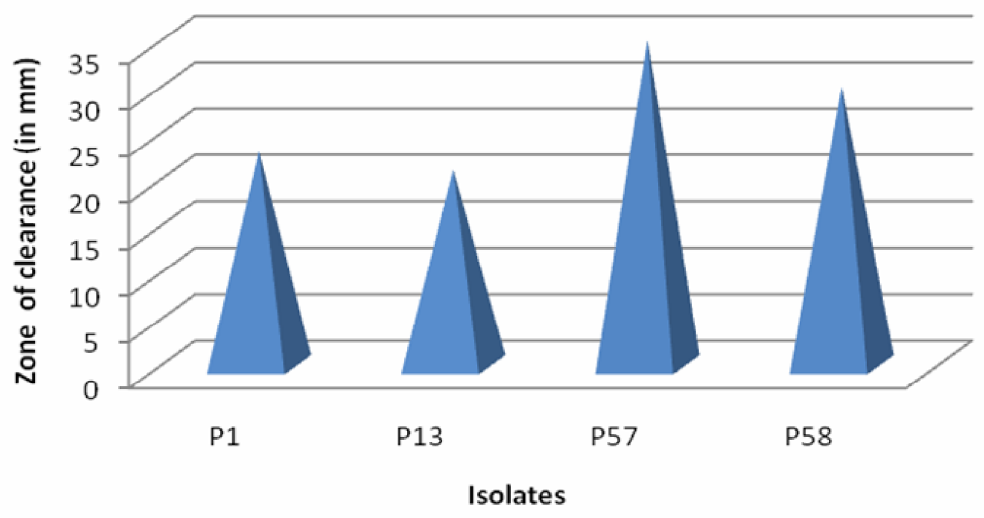


Int.J.Curr.Microbiol.App.Sci (2016) 5(1): 514-524

Fig. 4 : Effect of different incubation time on growth of isolates
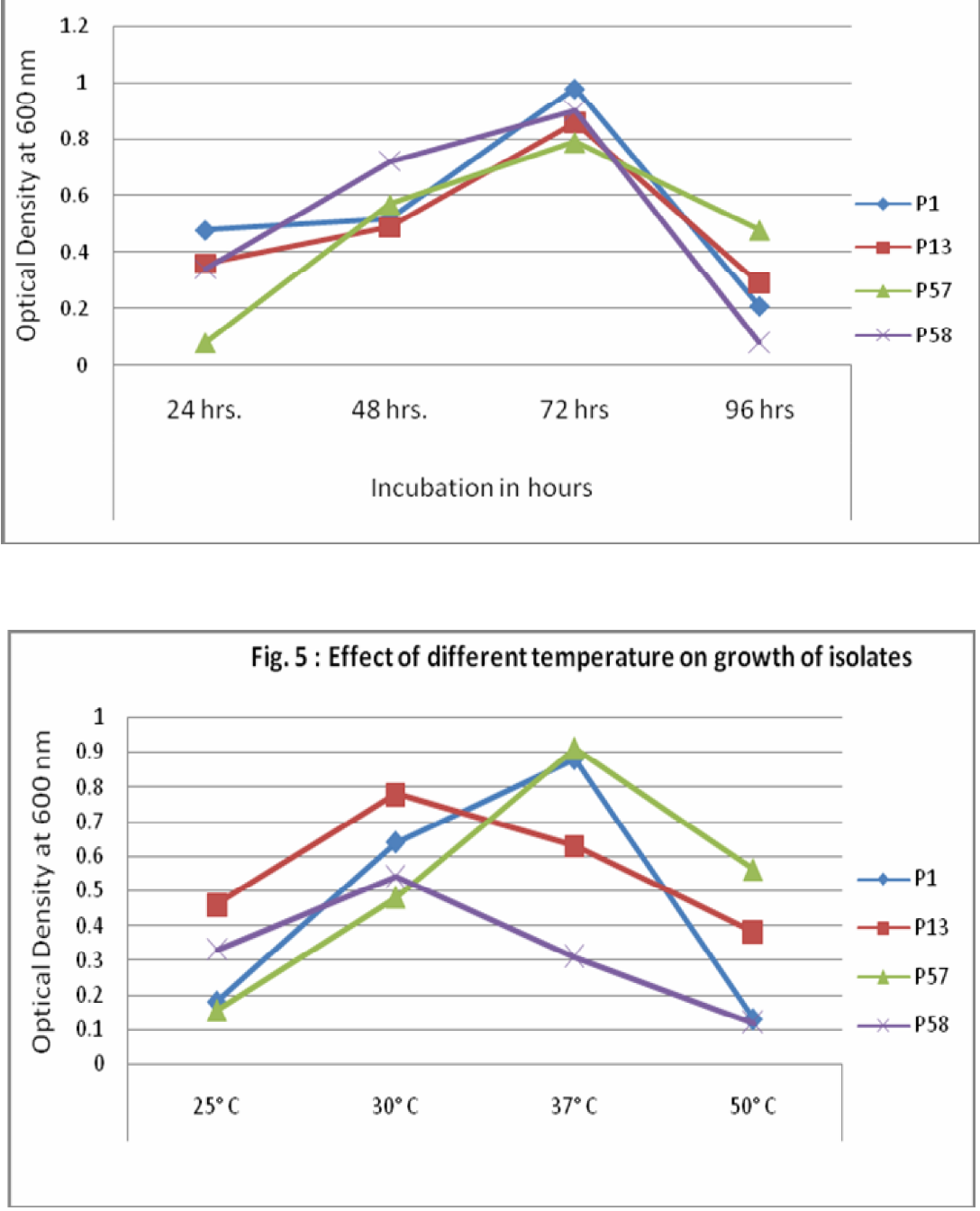

Fig. 6 : Effect of different $\mathrm{pH}$ on growth of isolates

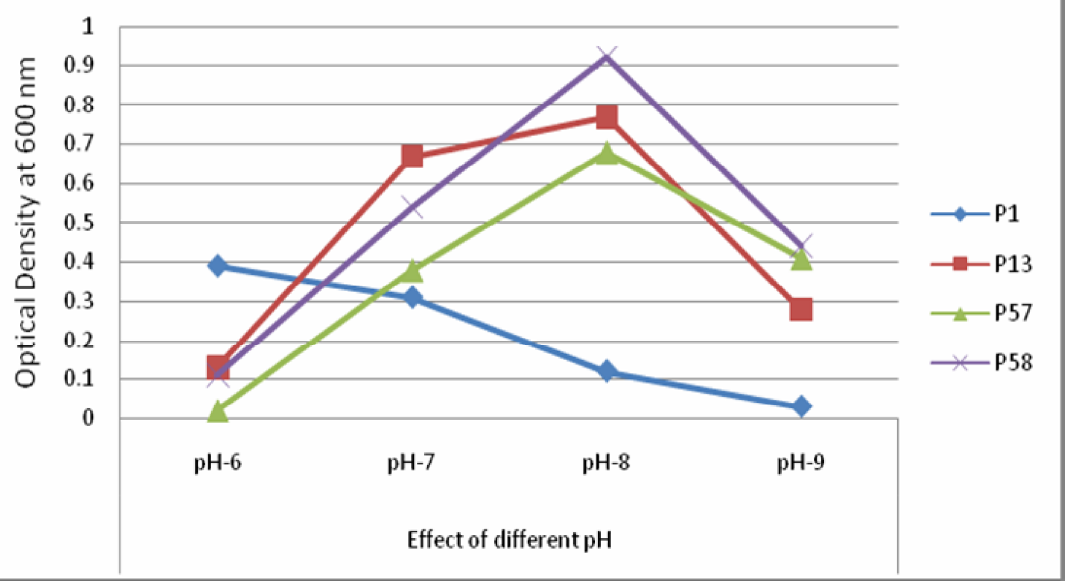




\section{Photo.1 Secondary Screening of Pactinase Producers}

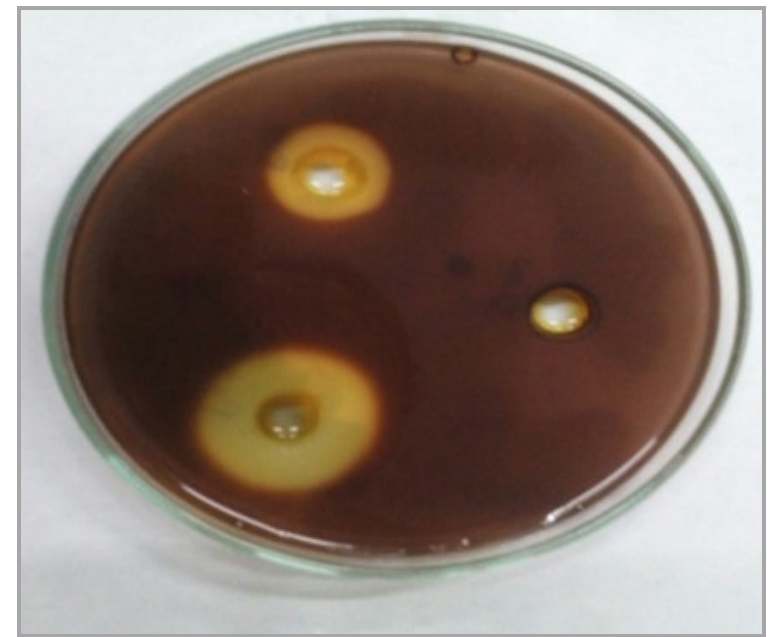

Optimum cultural conditions for pectinase production by $\mathrm{P} 1$ was found to be $37^{\circ} \mathrm{C}$ at $\mathrm{pH}$ of 6 , optimum temperature for $\mathrm{P} 13$ was found to be at $30^{\circ} \mathrm{C}$ at alkaline $\mathrm{pH} 8$. For P57 optimum temperature was at $37^{\circ} \mathrm{C}$ and at alkaline $\mathrm{pH} \mathrm{8,} \mathrm{optimum} \mathrm{temperature} \mathrm{for}$ P58 was found to be at $30^{\circ} \mathrm{C}$ at alkaline $\mathrm{pH}$ 8. Similar sort of result were observed by Marcia et al, 1999. He observed that optimum growth was found at alkaline $\mathrm{pH}$ for Bascillus species. Out of isolates 4 isolates namely Bacillus firmus (P1), Bacillus coagulans (P13), Bacillus endophyticus (P57) and Bacillus vietnamensis (P58) was found to be excellent pectinase producers in secondary screening as compared to others isolates. This is in agreement with study of Anna Roosdiana et al., in 2013, who also reported that Bacillus firmus is able to produce high percentage of pectinase. In other study by Janani et al., (2011), who also reported Bacillus species from agricultural soil as high pectinase producers.

In conclusion, the farm soil was found to be rich source for the isolation of pectinase producers. Screening of pectinase producing microbial strain from farm soil samples of
Akola region may help to supplement the increasing requirement of pectinase enzyme by the industries as the primary screening showed about $51 \%$ isolates were positive for pectinase activity. The identification reveals that the more number of isolates were belong to Bacillus spp. Further studies on molecular characterization and optimization of four maximum pectinase producing bacterial isolates from the study may be helpful for the production of industrially important enzyme in near future.

\section{References}

Anam Tariq and Zakia Latif (2012): Isolation and biochemical characterization of bacterial isolates producing different levels of polygalacturonases from various sources: African Journal of Microbiology Research, 6(45): 72597264.

Aneja KR (1996): Production of Pectolytic enzymes. In: Experiments in Microbiology, Plant Pathology, Tissue Culture and Mushroom Cultivation. Wishwa Prakashan, New Agel 
International $(P)$ Ltd., New Delhi, 3(1): 195- 197.

Anna Roosdiana, Sasangka Prasetyawan, Chanif Mahdi, and Sutrisno (2013): Production and Characterization of Bacillus firmus Pectinase: J. Pure App. Chem. Res., 2 (1): 35-41.

Arifa Jabeen, Qurat-ul-ain Hanif, Misbah Hussian, Anam Munawaar, Nisma Farooq, Shehar Bano (2015) : Screening, Isolation and Identification of pectinase producing bacterial strains from rotting fruits and determination of their pectinolytic activity: Open Access Journal Science Letters, 3(2): 42-45.

Janani, L. Karthik, Gaurav Kumar, K.V. Bhaskara Rao (2011): Screening of Pectinase Producing Microorganisms from Agricultural Waste Dump Soil: Asian Journal of Biochemical and Pharmaceutical Research, 1(2): 22312560.

Kashyap D.R., S. Chandra, A.Kaul and R. Tewari (2000): Production, purification and characterization of pectinase from Bacillus sp. DT7. World journal of Microbiology and Biotechnology, 16: 277-282.

Kumar M.P., M.Vijay Bhargavi (2014): Studies on Production, purification and molecular characterisation of polygalacturonase from Bacillus subtilis: European Journal of Biotechnology and Biosceince, 1 (5): 1-6.

Lalitha Kumara B., P Sudhakar, K Hemamalini, N Satya sree and $\mathrm{P}$ Vijetha (2014): Studies on Pectinase Production by Bacillus Subtilis using Agro-Industrial Wastes. Journal of Pharmaceutical, Biological and Chemical Sciences, 5(6): 338.

Mehta S.A., Rana Mithali, Shaikh Nilofer and Patel Nimisha (2013): Optomization of physiology parameters for pectinase production from soilisolates and its Applications in Fruit juice clarification: journals of Environmental Reseacrh and Development, 7(4A).

Torimiro N and Okonji.R.E (2013): A comparative study of pectinolytic enzyme production by Bacillus species. African Journal of Biotechnology, 12(46): 6498-6503.

Venkata E., Naga Rajuand, G. Divakar (2013): Production of pectinase by using Bacillus circulans isolated from dump yards of vegetable wastes, International journal of Pharmaceutical Science and Research, 4(7): 2615-2622.

\section{How to cite this article:}

Aaisha, G.A., and Barate, D.L. 2016. Isolation and Identification of Pectinolytic Bacteria from Soil Samples of Akola Region, India. Int.J.Curr.Microbiol.App.Sci. 5(1): 514-521 http://dx.doi.org/10.20546/ijcmas.2016.501.051 